Article

\title{
Environmental Taxes and Innovation in Chinese Textile Enterprises: Influence of Mediating Effects and Heterogeneous Factors
}

\author{
Yabin Yu ${ }^{1,2}$ and Hua Cheng $1, *(\mathbb{D}$ \\ 1 School of Economics and Management, Zhejiang Sci-Tech University, Hangzhou 310018, China; \\ yabinyu@cjlu.edu.cn \\ 2 College of Economics \& Management, China Jiliang University, Hangzhou 310018, China \\ * Correspondence: chenghua@zstu.edu.cn
}

Citation: Yu, Y.; Cheng, $\mathrm{H}$.

Environmental Taxes and Innovation in Chinese Textile Enterprises: Influence of Mediating Effects and Heterogeneous Factors. Sustainability 2021, 13, 4561. https://doi.org/ $10.3390 /$ su13084561

Academic Editor: Patrik Söderholm

Received: 23 March 2021

Accepted: 19 April 2021

Published: 20 April 2021

Publisher's Note: MDPI stays neutral with regard to jurisdictional claims in published maps and institutional affiliations.

Copyright: (c) 2021 by the authors. Licensee MDPI, Basel, Switzerland. This article is an open access article distributed under the terms and conditions of the Creative Commons Attribution (CC BY) license (https:/ / creativecommons.org/licenses/by/ $4.0 /)$.

\begin{abstract}
Climate change and environmental conditions call for more attention to be paid to ecofriendly economic behavior. As a market-oriented environmental regulation, environmental tax can stimulate and guide enterprises' environmental innovation in a neutral way. However, what elements connect the environmental tax and enterprise innovation activity together? Are all the enterprises' innovation activities affected by the environmental tax in the same way? To answer the questions, the study uses the data of Chinese textile listed companies between 2004 and 2018 to explore the intermediary role of manpower and capital investment in the innovation chain and further analyze the influence of the heterogeneous factors such as property right, segmented industry, and region. The results show that the environmental tax can effectively promote the innovation capital input of Chinese textile enterprises, and the innovation manpower input plays a partial mediation role. At the same time, environmental tax can effectively promote the innovation performance output of Chinese textile enterprises, and innovation capital input plays a complete mediation role. In addition, heterogeneous factors such as property right, segmented industry and region will affect the relation of environmental tax to innovation input and output quality and greenness to varying degrees. The study makes a profound analysis of the relation of environmental tax on Chinese textile enterprises innovation by using the microdata at the enterprise level, providing a more targeted reference for making policies in the future.
\end{abstract}

Keywords: environmental tax; innovation; textile enterprises; mediating effect; China

\section{Introduction}

Climate change and environmental conditions call for more attention to be paid to eco-friendly economic behavior [1,2]. As a market-oriented environmental regulation, environmental tax is an important tool for the government to adjust the behavior of ecoenvironmental stakeholders through financial means [3], which can stimulate and guide enterprises' environmental innovation behaviors in a neutral way. Market regulation tools such as finance, tax, and fees are more suitable for China's national conditions [4]. For more than 70 years, environmental fiscal and tax policies have evolved from nothing to a current comprehensive and rich policy system. However, at present, China's ecological and environmental problems are still very serious, and pollution prevention and control is still an arduous task [5]. Environmental tax, as a cost of enterprises, will virtually force enterprises to reduce costs. One of the most positive externalities behavior is technological innovation. In the long run, technological innovation can make the products and services provided by enterprises more innovative and environmentally friendly, improving the high-quality development ability, and reduce the operating costs to a certain extent, such as the cost of complying with environmental regulations, so as to enhance the market competitiveness further. As a resource-intensive and carbon-intensive industry, the textile 
industry is a key industry concerned with environmental regulation. At the same time, China is a big country in terms of textile production, and the textile industry is one of the pillar industries of traditional manufacturing in China. It has practical significance to choose the textile industry as the research topic of this study.

Research shows that environmental tax can significantly promote enterprises' green innovation, but it lags behind, and this promotion effect is mainly reflected in state-owned enterprises, large-scale enterprises, and enterprises with low financing constraints [6]. Even though the policy mix as "green environment tax + green technology R\&D subsidy + producer price subsidy"; "environmental tax + green technology R\&D subsidy, the government green procurement"; and "environmental taxes + green technology R\&D subsidy + consumers green price subsidies" constrains the production behavior of the enterprise by the punishment of environmental pollution and motivation of environmental technology R\&D, economic growth and environmental governance can be realized [7]. At the same time, the environmental tax can raise the utilization ratio of manufacturing capacity through cost effect and innovation compensation effect, helping to dissolve excess capacity and showing a more apparent innovation compensation effect. Therefore, it can make use of the environmental hard constraints to ease excess manufacturing capacity in China, adjusting our supply system to boost economic high-quality development [8]. At the same time, the progressive and dynamic environmental tax policy reflects the double dividend of promoting economic growth and reducing pollution level by correcting the excessive use of energy and achieves the goal of maximizing welfare along the whole path [9].

The aim of this study is to find how environmental tax affects the innovation activity of Chinese textile enterprises, to explore whether the innovation input of textile enterprises plays a mediating effect in the innovation chain, and to analyze further the influence of heterogeneous factors such as the property right, industry segmentation attributes, and regions on the mechanism. The biggest contribution of this paper is the in-depth analysis of heterogeneous factors on environmental tax to Chinese textile enterprise innovation, using the microdata at the enterprise level. Since the previous research usually uses statistical yearbook data, the level of analysis is limited. This study bridges the research gap at the enterprise level for heterogeneous analysis. Moreover, it is also of more practical significance to guide the subsequent innovation activities of enterprises. Additionally, in the past, this kind of research was conducted mostly on high-tech enterprises and paid little attention to the traditional manufacturing industry-the textile industry.

The rest of the paper will be arranged according to the following structure: Section 2 will introduce the theoretical basis of the impact of environmental taxes on the innovation of Chinese textile enterprises and put forward three important hypotheses accordingly. Section 3 will introduce data sources, variable definitions, and model contents. According to the properties of variables, fixed effect model, negative binomial model, and OLS model are comprehensively adopted in this study. Section 4 presents the model estimation results and compares the assumptions for analysis. At the end of this paper, the analysis results will be discussed and some suggestions will be provided for the formulation of environmental tax policies and the innovative practices of Chinese textile enterprises.

\section{Conceptual Framework and Hypothesis Development}

\subsection{Environmental Tax and Corporate Innovation Input}

As early as 1995, Porter and Linde proposed that innovation becomes the key in a dynamic competitive relationship. Well-designed environmental regulations can promote innovation, which can offset the cost of compliance with environmental regulations and become an advantage over other enterprises that do not face the same environmental regulations. Innovation can help companies reduce pollution and energy use at the same time. Therefore, the design of reasonable and strict environmental regulations can effectively improve the competitiveness of enterprises [10]. Considering the two control variables of industry scale and innovative human resource investment, the government's formulation of strict environmental regulation policies can effectively promote the imple- 
mentation of green technology innovation in pollution-intensive industries [11]. Therefore, the study hopes to verify whether innovative human capital plays a mediating effect in environmental tax on innovation capital input and puts forward the following suggestion:

Hypothesis 1 (H1). Environmental tax promotes innovation capital input of Chinese textile enterprises by influencing their innovation manpower expenditure (mediating effect).

\subsection{Environmental Tax and Corporate Innovation Output}

The ultimate goal of environmental regulation is to effectively promote innovation performance [12], which requires innovation input as a prerequisite. The mediating effect test finds that the collection of pollutant discharge fees and environmental protection financial expenditure will force enterprises to increase their R\&D intensity, thus promoting green technology innovation [4]. In addition, with the increase of investment in technology absorption and technological transformation, the mediating effect of domestic technology introduction in environmental regulation and green TFP gradually appears [13]. At the same time, technological innovation does play a mediating role between environmental regulation and environmental performance [14]. Therefore, this paper proposes the following hypothesis:

Hypothesis 2a (H2a). Environmental tax promotes the innovation performance of Chinese textile enterprises by influencing their innovation capital input (mediating effect).

In the past decade, the scale of China's green innovation has increased by more than 10 times, but the innovation direction has not noticeably turned green, and the quality did not start to improve until 2015 [15]. However, studies in the past two years have also shown that normal innovation and green innovation can complement and reinforce each other [16]. Additionally, the effect of the environmental tax on enterprise technological innovation is characterized by high-quality quantification [17]. However, in the absence of capacity constraint policies, enterprises often rely on scale effect to offset the pressure of environmental protection tax. It makes that the increase of environmental protection tax in China induces, not a "Porter effect," but a "negative incentive" for the development of regional green innovation capacity [3]. Therefore, this paper hopes to use detailed enterprise data to verify whether environmental tax can really improve the innovation quality and green innovation of Chinese textile enterprises. Thus, two sub-hypotheses of $\mathrm{H} 2$ are proposed as follows:

Hypothesis $\mathbf{2 b}(\mathbf{H} \mathbf{2 b})$. Environmental taxes can improve the innovation quality of Chinese textile enterprises.

Hypothesis 2c (H2c). Environmental tax can promote the green innovation of Chinese textile enterprises.

\subsection{The Role of Heterogeneous Factor}

The heterogeneity of enterprises affects whether the Porter hypothesis is correct and which version of the Porter hypothesis will influence the green innovation of enterprises [18]. Research shows that environmental tax can significantly promote enterprises' green innovation, which is mainly reflected in state-owned enterprises, large-scale enterprises, and enterprises with low financing constraints [19]. In addition, the marginal effect of environmental taxes on enterprises' green investment is positive and heterogeneous [20], which is positively correlated with enterprises' competitiveness and has quantile heterogeneity [21]. The positive impact of technological innovation on emission reduction also has quantile heterogeneity [22]. Various indications show that heterogeneity has become an important factor affecting environmental tax and innovation activities of textile enterprises. Therefore, we put forward the following hypothesis: 
Hypothesis 3a (H3a). The heterogeneous factors of Chinese textile enterprises will affect the effect of environmental taxes on enterprise innovation activities.

At present, the overall level of green innovation growth in China's manufacturing industry is relatively low, with large development space and significant industry heterogeneity [23]. The environmental tax collection standard adjustment policy plays a more prominent role in enterprises' green technology innovation in high-pollution industries, cities with strong policy enforcement, and areas implementing green tax policies [24]. In different geographical conditions, the time point when the government changes from "economic growth first" to "environment first" will also be different [25]. For example, the increase of pollutant discharge fees only plays a significant role in emission reduction in the eastern and central regions, and the emission reduction effect in the eastern region is greater, whereas for the western region, although the increase of pollutant discharge fee also has an emission reduction effect, it is not significant [26]. At the same time, in the eastern and central parts of China, environmental regulation can significantly promote ecological efficiency but not in the western parts [27]. As for the enterprise-level data, this paper has the opportunity to explore the influence mechanism of environmental taxes on the innovation activities of textile enterprises in the micro level of subdivision of the textile industry, enterprises with different property rights, and specific provinces. Hence, the following hypothesis is proposed:

Hypothesis $3 \mathbf{b}(\mathbf{H} 3 \mathbf{b})$. There are differences in the impact of environmental taxes on the innovation activities of Chinese textile enterprises in different sectors.

Hypothesis 3c (H3c). There are differences in the impact of environmental taxes on the innovation activities of Chinese textile enterprises with different property rights.

Hypothesis $3 \mathbf{d}(\mathbf{H} 3 \mathbf{d})$. There are differences in the impact of environmental taxes on the innovation activities of Chinese textile enterprises in different provinces.

\section{Methodology}

\subsection{Data Sources}

In this study, the data of 111 listed textile companies owned by A-shares in China from 2004 to 2018 are selected as samples, and the samples with missing core variables are eliminated. The financial data are from CSMAR (China Stock Market and Accounting Research Database), and the environmental tax part is manually sorted from the annual reports of Chinese textile listed companies. The patent data come from the National Intellectual Property Administration.

\subsection{Variable Measurement}

\subsubsection{Dependent Variables}

Innovation Input: Innovation input is measured in terms of R\&D capital input and innovation manpower input. Innovation capital input is mainly measured by the enterprise's R\&D expenditure [28], and innovation manpower input is mainly measured by the proportion of R\&D personnel in the total number of employees [29].

Innovation Performance: Innovation input is to produce innovation performance, which is specifically measured by the number of patents [30].

Innovation Quality: Innovation activities depend on quantity and quality. As a form of patent with higher content of innovation, invention patent is often used to measure innovation quality [31].

Green Innovation: Since the paper aims to study the impact of environmental taxes on enterprise innovation, green innovation can better reflect the effect of environmental tax. Therefore, the quantity of green innovation is measured by the total number of green patents, and the quality of green innovation is measured by the number of green 
invention patents. At the same time, this paper adopts both narrow and broad definitions to carry out statistics on green patents. In the narrow definition, the green patent data are selected according to the official definition of green patent corresponding to WIPO [32] of all patents of the sample enterprise from 2004 to 2018. A total of 189 green patents have been obtained, including 102 green patents for invention and 87 green patents for utility models. By reading the introduction of the patent item by item, we manually marked all the environment-related patents as green patents. The keywords include but are not limited to "energy saving, recycling, pollution, environmental protection, ecology, and green." In this way, we obtained a total of 885 green patents (715 pieces left in samples after screening based on environmental tax and R\&D expenditure data).

\subsubsection{Independent Variables}

Environmental Tax: According to the OECD's definition, environmentally related taxes are an important instrument for governments to shape relative prices of goods and services. Following Bi and $\mathrm{Yu}$ [20], and $\mathrm{Yu}$, Zhang, and Bi [19], this article adopts the generalized definition of environmental taxes to measure environmental taxes (EnTax), mainly including green taxes, city construction fee, land use tax, water conservancy construction fund, embankments fee, resource tax, and all environmental protection relevant taxes and fees.

\subsubsection{Control Variables}

Since the profit level of an enterprise will greatly affect its expenditure on $R \& D$, the growth rate of revenue, cost-profit margin, and return-on-net assets (ROE) are incorporated into the model as control variables. In addition, large enterprises generally have stronger R\&D capability than small enterprises, but small enterprises have more incentive to innovate, and therefore, the size of enterprises is also controlled.

In addition, the influence of heterogeneous factors such as industry segmentation, property right nature, and province where the enterprise is located on the estimation model is controlled.

\subsection{Model Set}

Based on Porter's hypothesis, well-designed environmental regulations can effectively stimulate innovation [10]. This is the basis to construct the two innovation chains in Figure 1, as the main line on which to set the model. Firstly, as a market-based environmental regulation, environmental tax can be regarded as a well-designed environmental regulation. Secondly, from the perspective of input-output, there are probable intermediary factors, such as innovation input, in the path of environmental regulation stimulating enterprise innovation. In addition, the influence of heterogeneous factors will be tested by grouping regression.

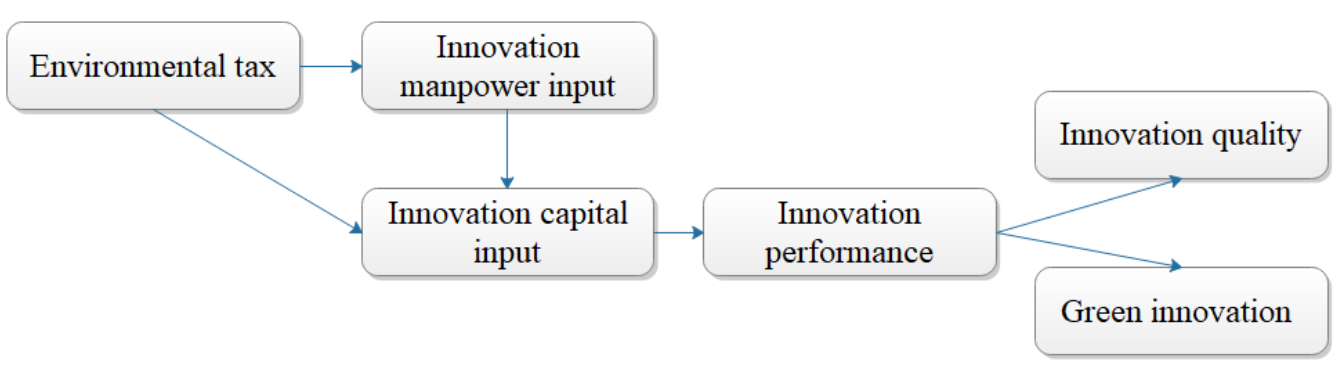

Figure 1. Innovation chain framework.

The first innovation chain is that environmental tax affects the investment of enterprise innovation capital by affecting the investment of enterprise innovation manpower. It is a logical chain that environmental tax forces enterprises to innovate from human investment to capital investment since innovation activities of enterprises ultimately need to be carried 
out by innovative personnel. Meanwhile, this study hopes to demonstrate the mediating effect of innovative manpower input on environmental tax and innovative capital input.

$$
\operatorname{lnRDexp} p_{i t}=\alpha+\beta_{1} \operatorname{lnEntax}_{i t}+\beta_{2} \text { Rdemr }_{i t}+\beta_{3} \operatorname{lnSize}_{i t}+\beta_{4} \operatorname{lninrate}_{i t}+\beta_{5} \mathrm{CPR}_{\mathrm{it}}+\beta_{6} \mathrm{ROE}_{\mathrm{it}}+\mathrm{V}_{\mathrm{i}}+\varepsilon_{\mathrm{it}}
$$

Since the sample is panel data, model 1 uses the fixed effect model to fix the individual effect and time effect. At the same time, in order to eliminate heteroscedasticity, the logarithmic transformation is applied to the nonproportional variables.

The second innovation chain is that environmental tax affects the innovation performance of enterprises by influencing their innovation capital input. Model 2 also tests the mediating effect of the innovation capital input of enterprises. At the same time, the study describes the innovation performance from the innovation quality and green innovation two aspects. Since the number of patents is used to measure innovation performance, the negative binomial model is more appropriate to apply here.

$$
\text { Patent }_{i t}=\alpha+\beta_{1} \operatorname{lnEntax} \text { it }_{1}+\beta_{2} \operatorname{lnRDexp_{it}}+\beta_{3} \operatorname{lnSize}_{i t}+\beta_{4} \operatorname{lninrate}_{i t}+\beta_{5} \mathrm{CPR}_{i t}+\beta_{6} \mathrm{ROE}_{i t}+\mathrm{V}_{\mathrm{i}}+\varepsilon_{i t}
$$

where i represents each sample textile enterprise; $t$ represents each year, $t=2004,2005, \ldots$, 2018; RDexp represents innovation capital input; Patent represents innovation performance; Entax represents environmental tax; Rdemr represents innovation manpower; Size, Ininrate, $\mathrm{CPR}$ and ROE, respectively, represent enterprise size, revenue growth rate, cost-profit margin, and return-on-net assets as control variables. $\alpha$ is the intercept that does not change with individuals; $V_{i}$ is the individual effect; $\beta$ is the parameter to be estimated; $\varepsilon_{i t}$ is the error term subject to normal distribution.

\section{Results}

\subsection{Descriptive Statistics}

Table 1 is the descriptive statistics of major variables. The levels of environmental tax, innovation input, and innovation performance are very uneven in the different Chinese textile enterprises. The different levels of environmental taxes and innovation capital can reach hundreds of millions. Additionally, the level of innovation performance (patent, invention patent, and green patent) and R\&D staff ratio between textile enterprises also have a very large difference. This also shows that we need to consider the influence of heterogeneous factors on the effect of environmental tax and innovation activities of Chinese textile enterprises.

Table 1. Descriptive statistics of main variables.

\begin{tabular}{cccccc}
\hline Variables & Unit & Mean & SD & Min & Max \\
\hline Entax (Environmental tax) & RMB & $9,480,000$ & $12,760,000$ & 2371 & $151,700,000$ \\
Rdexp (R\&D input) & RMB & $58,430,000$ & $90,890,000$ & 238,547 & $956,200,000$ \\
Invention & Piece & 3.670 & 6.950 & 0 & 68 \\
Patent & Piece & 13.10 & 23.50 & 0 & 216 \\
Grepat (Green patent) & Piece & 0.917 & 1.820 & 0 & 0 \\
Rdemr (R\&D staff ratio) & $\%$ & 0.0828 & 0.0734 & 0.392 \\
\hline
\end{tabular}

\subsection{The Model Results}

Based on the theoretical basis and research hypothesis, the study first adopts the sequential test method [33] to verify the partial mediating effect of enterprise innovation manpower input as environmental tax on the enterprise's innovation capital input. First of all, it can be seen from model 1 and model 2 (Table 2) that environmental tax has significant positive effects on both innovative capital input and innovative manpower input of Chinese textile enterprises. After adding innovative manpower input into the model of environmental tax and innovative capital input, environmental tax still has significant positive effects on innovative capital input. It can be inferred that, on the one hand, environmental tax directly promotes the innovative capital input of Chinese textile enterprises; on the other hand, it also has a positive impact on the innovative capital input through the innovative manpower input. 
Table 2. Environmental tax-innovative manpower input-innovative capital input model.

\begin{tabular}{cccc}
\hline & $\mathbf{( 1 )}$ & $\mathbf{( 2 )}$ & $\mathbf{( 3 )}$ \\
\hline Variables & RD1 & RD Employee & RD2 \\
\hline lnEnTax & $0.227^{* * *}$ & $0.009^{*}$ & $0.194^{* * *}$ \\
Rdemr & $(4.05)$ & $(1.96)$ & $(3.49)$ \\
& & & $3.832^{* * *}$ \\
lnSize & & & $(3.53)$ \\
& $0.745^{* * *}$ & $0.038^{* * *}$ & $0.601 * * *$ \\
Ininrate & $(5.58)$ & $(3.77)$ & $(4.73)$ \\
& -0.165 & $-0.020^{* *}$ & -0.086 \\
CPR & $(-1.29)$ & $(-2.57)$ & $(-0.75)$ \\
& 0.442 & 0.008 & 0.411 \\
ROE & $(1.39)$ & $(0.21)$ & $(1.11)$ \\
& -0.311 & -0.038 & -0.164 \\
Constant & $(-1.23)$ & $(-1.05)$ & $(-0.55)$ \\
& -2.572 & $-0.866^{* * *}$ & 0.746 \\
Observations & $(-0.99)$ & $(-3.93)$ & $(0.30)$ \\
R-squared & 780 & 780 & 780 \\
Number of codes & 0.365 & 0.226 & 0.412 \\
Individual & 105 & 105 & 105 \\
Year & YES & YES & YES \\
\hline
\end{tabular}

Robust Z-statistics in parentheses ${ }^{* * *} p<0.01,{ }^{* *} p<0.05,{ }^{*} p<0.1$.

The innovation capital input of enterprises can improve the innovation performance; therefore, can environmental tax improve the innovation performance by promoting the innovation capital input of enterprises? Innovation performance was measured by the number of patents and negative binomial regression was used. Model 4-6 (Table 3) shows that $R \& D$ investment has a complete mediating effect between environmental tax and innovation performance [34]. In other words, environmental tax can promote the innovation performance of Chinese textile enterprises by promoting their innovation capital input.

Table 3. Environmental tax-innovative capital input-innovation performance model.

\begin{tabular}{cccc}
\hline & $\mathbf{( 4 )}$ & $\mathbf{( 5 )}$ & $\mathbf{( 6 )}$ \\
\hline Variables & Patent1 & RDexp & Patent2 \\
\hline lnEnTax & $0.297^{* * *}$ & $0.227^{* * * *}$ & 0.004 \\
lnRDexp & $(2.61)$ & $(4.05)$ & $(0.07)$ \\
& & & $0.277^{* *}$ \\
lnSize & & & $-0.137)$ \\
& -0.062 & $0.745^{* * *}$ & $(-1.00)$ \\
Ininrate & $(-0.30)$ & $(5.58)$ & -0.144 \\
& -0.149 & -0.165 & $(-0.72)$ \\
CPR & $(-0.58)$ & $(-1.29)$ & -0.164 \\
& 0.936 & 0.442 & $(-0.15)$ \\
ROE & $(0.97)$ & $(1.39)$ & -0.283 \\
& -0.340 & -0.311 & $(-0.36)$ \\
Constant & $(-0.49)$ & $(-1.23)$ & -2.102 \\
& -0.745 & -2.572 & $(-0.83)$ \\
Observations & $(-0.20)$ & $(-0.99)$ & YES \\
Individual & 780 & 780 & YES \\
Year & YES & YES & 90 \\
Number of codes & YES & YES & \\
R-squared & & 105 & \\
\hline
\end{tabular}

Robust $\mathrm{z}$-statistics in parentheses ${ }^{* * *} p<0.01,{ }^{* *} p<0.05$. 
The negative binomial regression model is used to test the effect of the environmental tax on innovation quality and green innovation. The results in Table 4 show that the environmental tax has no significant effect on the innovation quality of Chinese textile enterprises, but it has a significant promoting effect on the non-invention patents. Although environmental tax also has a significant promoting effect on green innovation, it is not as significant as the environmental tax on non-green innovation. In general, the environmental tax has a more significant promoting effect on non-invention patents and non-green patents of Chinese textile enterprises. In other words, the promoting effect of the environmental tax on innovation quality and green innovation still needs to be improved.

Table 4. Environmental tax-innovation performance (quality/green) model.

\begin{tabular}{|c|c|c|c|c|}
\hline & (7) & (7) & (8) & (8) \\
\hline Variables & Invention & NonInven & Grepat & NonGre \\
\hline \multirow[t]{2}{*}{$\operatorname{lnEnTax}$} & 0.100 & $0.415^{* * *}$ & $0.152 *$ & $0.280^{* * *}$ \\
\hline & $(0.67)$ & $(3.68)$ & $(1.70)$ & $(3.11)$ \\
\hline \multirow[t]{2}{*}{$\ln$ Size } & 0.240 & -0.168 & 0.138 & 0.005 \\
\hline & $(1.02)$ & $(-0.79)$ & $(0.68)$ & $(0.03)$ \\
\hline \multirow[t]{2}{*}{ Ininrate } & -0.238 & -0.104 & -0.506 & 0.200 \\
\hline & $(-0.72)$ & $(-0.37)$ & $(-1.60)$ & $(0.60)$ \\
\hline \multirow[t]{2}{*}{ CPR } & -0.083 & 1.188 & -1.649 & 0.128 \\
\hline & $(-0.07)$ & $(0.97)$ & $(-1.12)$ & $(0.10)$ \\
\hline \multirow[t]{2}{*}{ ROE } & -0.811 & 0.011 & -0.114 & 0.132 \\
\hline & $(-1.25)$ & $(0.01)$ & $(-0.20)$ & $(0.16)$ \\
\hline \multirow[t]{2}{*}{ Constant } & -5.406 & -0.650 & -5.264 & -1.991 \\
\hline & $(-1.36)$ & $(-0.16)$ & $(-1.43)$ & $(-0.54)$ \\
\hline Observations & 780 & 780 & 780 & 780 \\
\hline Individual & YES & YES & YES & YES \\
\hline Year & YES & YES & YES & YES \\
\hline
\end{tabular}

Robust t-statistics in parentheses ${ }^{* * *} p<0.01,{ }^{*} p<0.1$.

Since the study adopts the microdata at the enterprise level, we have the opportunity to analyze the influence of different heterogeneous factors of Chinese textile enterprises on environmental tax and enterprise innovation input (Table 5).

Table 5. Environmental tax-innovative capital-heterogeneity (industry/property right) model.

\begin{tabular}{|c|c|c|c|c|c|c|c|}
\hline & (9) & (10) & (10) & (10) & (10) & (11) & (11) \\
\hline Variables & Total & Fashion & Textile & Fiber & Leather & Other & Private \\
\hline $\operatorname{lnEnTax}$ & $\begin{array}{c}0.231^{* * *} \\
(6.44)\end{array}$ & $\begin{array}{c}0.115^{* * *} \\
(3.10)\end{array}$ & $\begin{array}{c}0.517^{* * *} \\
(7.29)\end{array}$ & $\begin{array}{l}0.140 \\
(1.44)\end{array}$ & $\begin{array}{c}0.283 * \\
(1.69)\end{array}$ & $\begin{array}{c}0.292 * * * \\
(2.75)\end{array}$ & $\begin{array}{c}0.227^{* * *} \\
(6.48)\end{array}$ \\
\hline Rdemr & $\begin{array}{c}4.039 * * * \\
(8.04)\end{array}$ & $\begin{array}{c}3.165^{* * *} \\
(4.32)\end{array}$ & $\begin{array}{c}4.847^{* * *} \\
(5.70)\end{array}$ & $\begin{array}{c}7.768^{* * *} \\
(5.14)\end{array}$ & $\begin{array}{c}1.532 * \\
(1.78)\end{array}$ & $\begin{array}{c}9.167 * * * \\
(5.61)\end{array}$ & $\begin{array}{c}2.786^{* * *} \\
(5.74)\end{array}$ \\
\hline $\operatorname{lnSize}$ & $\begin{array}{c}0.511^{* * *} \\
(10.43)\end{array}$ & $\begin{array}{c}0.474^{* * *} \\
(9.73)\end{array}$ & $\begin{array}{c}0.469 * * * \\
(4.43)\end{array}$ & $\begin{array}{c}0.545^{* * *} \\
(3.58)\end{array}$ & $\begin{array}{c}0.596^{* *} \\
(2.66)\end{array}$ & $\begin{array}{c}0.512 * * * \\
(3.47)\end{array}$ & $\begin{array}{c}0.523 * * * \\
(10.91)\end{array}$ \\
\hline Ininrate & $\begin{array}{l}0.213 \\
(1.51)\end{array}$ & $\begin{array}{l}0.027 \\
(0.19)\end{array}$ & $\begin{array}{l}0.379 \\
(1.27)\end{array}$ & $\begin{array}{l}0.398 \\
(1.07)\end{array}$ & $\begin{array}{l}0.644 \\
(0.97)\end{array}$ & $\begin{array}{l}0.275 \\
(0.59)\end{array}$ & $\begin{array}{l}0.210 \\
(1.56)\end{array}$ \\
\hline CPR & $\begin{array}{l}0.373 \\
(0.80)\end{array}$ & $\begin{array}{l}-0.885 \\
(-1.63)\end{array}$ & $\begin{array}{l}-0.946 \\
(-0.90)\end{array}$ & $\begin{array}{c}2.923^{* *} \\
(2.32)\end{array}$ & $\begin{array}{l}-1.023 \\
(-0.45)\end{array}$ & $\begin{array}{l}1.935 \\
(1.26)\end{array}$ & $\begin{array}{l}0.054 \\
(0.12)\end{array}$ \\
\hline $\mathrm{ROE}$ & $\begin{array}{l}0.583 \text { * } \\
(1.79)\end{array}$ & $\begin{array}{l}0.616 \\
(1.16)\end{array}$ & $\begin{array}{c}1.568 * \\
(1.74)\end{array}$ & $\begin{array}{l}-0.023 \\
(-0.04)\end{array}$ & $\begin{array}{l}2.025 \\
(0.75)\end{array}$ & $\begin{array}{l}0.621 \\
(0.64)\end{array}$ & $\begin{array}{l}0.328 \\
(1.03)\end{array}$ \\
\hline Constant & $\begin{array}{c}2.014^{* *} \\
(2.44)\end{array}$ & $\begin{array}{c}4.893^{* * *} \\
(5.77)\end{array}$ & $\begin{array}{l}-1.609 \\
(-0.97)\end{array}$ & $\begin{array}{l}2.225 \\
(0.83)\end{array}$ & $\begin{array}{l}-0.451 \\
(-0.13)\end{array}$ & $\begin{array}{l}0.392 \\
(0.15)\end{array}$ & $\begin{array}{c}2.054^{* *} \\
(2.58)\end{array}$ \\
\hline Observations & 780 & 268 & 267 & 184 & 61 & 185 & 595 \\
\hline R-squared & 0.410 & 0.504 & 0.593 & 0.323 & 0.438 & 0.360 & 0.477 \\
\hline
\end{tabular}

t-statistics in parentheses ${ }^{* * *} p<0.01,{ }^{* *} p<0.05,{ }^{*} p<0.1$. 
In general, we find that both environmental tax and innovative manpower input have a significant promoting effect on innovation capital input of enterprises, and the latter has a more significant promoting effect than that of environmental tax.

However, the effect is indeed different in each segmented industry: In the textile industry, environmental tax has the most significant promoting effect on enterprise innovation capital investment, followed by the leather and fashion industry, and fiber industry is relatively insignificant.

The property right has little influence on the environmental tax and innovation capital input of enterprises. Additionally, nonprivate enterprises are slightly better than private enterprises in the degree of promoting the innovation capital input of enterprises by the environmental tax.

In terms of geography, we have more specific provincial data for model analysis (Table 6). Shandong, Jiangsu, Zhejiang, Fujian, and Guangdong have always been big textile provinces, and the sample sizes of these provinces are also more adequate. The results show that in Jiangsu and Fujian, the environmental tax has the most significant promoting effect on the innovative capital input of textile enterprises, followed by Beijing, Shandong, Guangdong, and Zhejiang, with a significantly higher promotion degree than the other provinces, which is also closely related to the geographical distribution of textile enterprises.

Table 6. Environmental tax-innovative capital-heterogeneity (province) model.

\begin{tabular}{|c|c|c|c|c|c|c|}
\hline & (12) & (12) & (12) & (12) & (12) & (12) \\
\hline Variables & Zhejiang & Jiangsu & Guangdong & Shandong & Fujian & Beijing \\
\hline $\operatorname{lnEnTax}$ & $\begin{array}{c}0.115^{* *} \\
(2.42)\end{array}$ & $\begin{array}{c}0.560^{* * *} \\
(4.40)\end{array}$ & $\begin{array}{c}0.279 * * * \\
(3.30)\end{array}$ & $\begin{array}{c}0.295^{* *} \\
(2.28)\end{array}$ & $\begin{array}{c}0.527^{* * *} \\
(3.00)\end{array}$ & $\begin{array}{c}0.474^{* * *} \\
(3.51)\end{array}$ \\
\hline Rdemr & $\begin{array}{c}2.981^{* * * *} \\
(3.46)\end{array}$ & $\begin{array}{c}6.943^{* * *} \\
(4.26)\end{array}$ & $\begin{array}{c}5.455^{* * * *} \\
(3.27)\end{array}$ & $\begin{array}{l}2.247 \\
(1.40)\end{array}$ & $\begin{array}{c}5.279 * * * \\
(4.45)\end{array}$ & $\begin{array}{c}1.695^{* *} \\
(2.61)\end{array}$ \\
\hline $\operatorname{lnSize}$ & $\begin{array}{c}0.590 * * * \\
(10.12)\end{array}$ & $\begin{array}{c}-0.424^{* *} \\
(-2.52)\end{array}$ & $\begin{array}{c}0.337^{*} \\
(1.99)\end{array}$ & $\begin{array}{c}0.471 \text { * } \\
(1.77)\end{array}$ & $\begin{array}{c}0.544^{* *} \\
(2.42)\end{array}$ & $\begin{array}{c}0.381 * * * \\
(4.67)\end{array}$ \\
\hline Ininrate & $\begin{array}{c}0.611^{* * *} \\
(2.68)\end{array}$ & $\begin{array}{c}0.690 * \\
(1.91)\end{array}$ & $\begin{array}{l}-0.176 \\
(-0.78)\end{array}$ & $\begin{array}{l}-0.167 \\
(-0.30)\end{array}$ & $\begin{array}{l}-0.683 \\
(-1.62)\end{array}$ & $\begin{array}{l}-0.117 \\
(-0.78)\end{array}$ \\
\hline CPR & $\begin{array}{c}-1.946^{* * *} \\
(-2.83)\end{array}$ & $\begin{array}{l}4.218 * \\
(1.97)\end{array}$ & $\begin{array}{l}-1.195 \\
(-1.36)\end{array}$ & $\begin{array}{c}3.387 * * * \\
(2.70)\end{array}$ & $\begin{array}{c}-3.852 * * \\
(-2.08)\end{array}$ & $\begin{array}{l}-0.273 \\
(-0.49)\end{array}$ \\
\hline $\mathrm{ROE}$ & $\begin{array}{l}1.054 \text { * } \\
(1.82)\end{array}$ & $\begin{array}{l}-2.587 \\
(-1.61)\end{array}$ & $\begin{array}{l}0.211 \\
(0.18)\end{array}$ & $\begin{array}{l}-0.277 \\
(-0.43)\end{array}$ & $\begin{array}{c}3.830 * * * \\
(2.85)\end{array}$ & $\begin{array}{c}1.340 * * \\
(2.30)\end{array}$ \\
\hline Constant & $\begin{array}{c}2.553 * * * \\
(2.67)\end{array}$ & $\begin{array}{c}16.577^{* * * *} \\
(5.67)\end{array}$ & $\begin{array}{l}5.329 * \\
(1.69)\end{array}$ & $\begin{array}{l}2.097 \\
(0.44)\end{array}$ & $\begin{array}{l}-3.244 \\
(-0.88)\end{array}$ & $\begin{array}{l}1.897^{*} \\
(1.93)\end{array}$ \\
\hline Observations & 229 & 123 & 75 & 72 & 55 & 30 \\
\hline R-squared & 0.572 & 0.352 & 0.524 & 0.389 & 0.686 & 0.957 \\
\hline
\end{tabular}

t-statistics in parentheses ${ }^{* *} p<0.01,{ }^{* *} p<0.05,{ }^{*} p<0.1$.

In addition, innovation performance is taken as the dependent variable (Table 7). In general, we can see that environmental tax has a significant effect on the innovation performance of Chinese textile enterprises, and it is most obvious in the textile and fiber subindustries. In terms of property rights, the environmental tax in private textile enterprises also plays a significant role in promoting innovative performance. After further dividing innovation performance into innovation quality and green innovation performance (Table 8), we regret to find that in private textile enterprises, environmental tax can only significantly promote non-invention patent and non-green patent, indicating that environmental tax still has a long way to go in improving innovation quality and green performance. 
Table 7. Environmental tax-innovation performance-heterogeneity (industry/property right) model.

\begin{tabular}{|c|c|c|c|c|c|c|c|}
\hline & (13) & (14) & (14) & (14) & (14) & (15) & (15) \\
\hline Variables & All & Fashion & Textile & Fiber & Leather & Other & Private \\
\hline $\operatorname{lnEnTax}$ & $\begin{array}{c}0.209 * * * \\
(3.65)\end{array}$ & $\begin{array}{l}0.096 \\
(0.75)\end{array}$ & $\begin{array}{c}0.265^{* * *} \\
(2.66)\end{array}$ & $\begin{array}{c}0.235 \text { ** } \\
(2.61)\end{array}$ & $\begin{array}{l}0.209 \\
(0.44)\end{array}$ & $\begin{array}{l}-0.026 \\
(-0.19)\end{array}$ & $\begin{array}{c}0.311 \text { *** } \\
(4.79)\end{array}$ \\
\hline $\ln R D \exp$ & $\begin{array}{l}0.025 \\
(0.47)\end{array}$ & $\begin{array}{l}-0.149 \\
(-0.81)\end{array}$ & $\begin{array}{l}-0.137 * \\
(-1.88)\end{array}$ & $\begin{array}{c}0.217 * * * \\
(3.39)\end{array}$ & $\begin{array}{l}0.396 \\
(1.01)\end{array}$ & $\begin{array}{c}0.220 * * * \\
(3.43)\end{array}$ & $\begin{array}{c}-0.165^{* *} \\
(-2.54)\end{array}$ \\
\hline $\operatorname{lnSize}$ & $\begin{array}{l}-0.032 \\
(-0.34)\end{array}$ & $\begin{array}{l}0.305 \\
(1.50)\end{array}$ & $\begin{array}{l}0.234 \\
(1.41)\end{array}$ & $\begin{array}{c}-0.296^{* *} \\
(-2.03)\end{array}$ & $\begin{array}{l}-1.026 \\
(-1.50)\end{array}$ & $\begin{array}{l}-0.136 \\
(-0.68)\end{array}$ & $\begin{array}{l}0.123 \\
(1.23)\end{array}$ \\
\hline Ininrate & $\begin{array}{l}-0.032 \\
(-0.16)\end{array}$ & $\begin{array}{l}-0.158 \\
(-0.59)\end{array}$ & $\begin{array}{l}0.706 \\
(1.37)\end{array}$ & $\begin{array}{l}0.215 \\
(0.70)\end{array}$ & $\begin{array}{l}0.012 \\
(0.01)\end{array}$ & $\begin{array}{l}0.374 \\
(0.98)\end{array}$ & $\begin{array}{l}-0.160 \\
(-0.76)\end{array}$ \\
\hline CPR & $\begin{array}{l}0.642 \\
(1.09)\end{array}$ & $\begin{array}{l}-0.243 \\
(-0.20)\end{array}$ & $\begin{array}{l}-0.457 \\
(-0.32)\end{array}$ & $\begin{array}{l}0.048 \\
(0.05)\end{array}$ & $\begin{array}{c}24.467^{* * *} \\
(4.10)\end{array}$ & $\begin{array}{l}0.770 \\
(0.49)\end{array}$ & $\begin{array}{l}0.498 \\
(0.80)\end{array}$ \\
\hline $\mathrm{ROE}$ & $\begin{array}{l}-0.276 \\
(-0.83)\end{array}$ & $\begin{array}{l}-0.024 \\
(-0.02)\end{array}$ & $\begin{array}{l}1.403 \\
(1.24)\end{array}$ & $\begin{array}{c}-0.737 * \\
(-1.91)\end{array}$ & $\begin{array}{c}-13.075 * * \\
(-2.40)\end{array}$ & $\begin{array}{l}-0.559 \\
(-0.51)\end{array}$ & $\begin{array}{l}-0.221 \\
(-0.65)\end{array}$ \\
\hline Constant & $\begin{array}{l}-0.762 \\
(-0.55)\end{array}$ & $\begin{array}{l}-3.323 \\
(-1.23)\end{array}$ & $\begin{array}{l}-4.602 * \\
(-1.67)\end{array}$ & $\begin{array}{l}1.036 \\
(0.41)\end{array}$ & $\begin{array}{c}13.805 \\
(1.38)\end{array}$ & $\begin{array}{l}1.481 \\
(0.45)\end{array}$ & $\begin{array}{l}-2.278 \\
(-1.44)\end{array}$ \\
\hline Observations & 538 & 163 & 197 & 134 & 44 & 124 & 414 \\
\hline R-squared & 0.047 & 0.045 & 0.115 & 0.131 & 0.326 & 0.071 & 0.094 \\
\hline
\end{tabular}

t-statistics in parentheses ${ }^{* * *} p<0.01,{ }^{* *} p<0.05, * p<0.1$

Table 8. Environmental tax-innovation performance (quality/green)-heterogeneity (property right) model.

\begin{tabular}{ccccc}
\hline & $\mathbf{( 1 6 )}$ & $\mathbf{( 1 6 )}$ & $\mathbf{( 1 7 )}$ & $\mathbf{( 1 7 )}$ \\
\hline Variables & Other & Private & Other & Private \\
\hline $\operatorname{lnEnTax}$ & -0.076 & $0.274^{* * *}$ & -0.159 & $0.224^{* * *}$ \\
& $(-0.51)$ & $(4.00)$ & $(-1.53)$ & $(3.98)$ \\
$\ln$ RDexp & $0.274^{* * *}$ & $-0.212^{* * *}$ & $0.238^{* * *}$ & -0.000 \\
& $(3.82)$ & $(-2.73)$ & $(4.78)$ & $(-0.00)$ \\
lnSize & -0.103 & 0.167 & 0.261 & -0.020 \\
& $(-0.47)$ & $(1.53)$ & $(1.19)$ & $(-0.21)$ \\
Ininrate & 0.024 & -0.125 & 0.093 & 0.014 \\
& $(0.06)$ & $(-0.55)$ & $(0.32)$ & $(0.05)$ \\
CPR & 2.242 & 0.610 & -0.054 & -0.580 \\
& $(1.34)$ & $(0.76)$ & $(-0.04)$ & $(-0.84)$ \\
ROE & -1.064 & 0.070 & 0.425 & 0.539 \\
& $(-1.02)$ & $(0.13)$ & $(0.86)$ & $(1.06)$ \\
Constant & 0.122 & -2.115 & -5.560 & -0.843 \\
& $(0.03)$ & $(-1.24)$ & $(-1.47)$ & $(-0.58)$ \\
Observations & 103 & 354 & 129 & 445 \\
R-squared & 0.082 & 0.072 & 0.128 & 0.055 \\
\hline
\end{tabular}

t-statistics in parentheses ${ }^{* * *} p<0.01$.

\subsection{Robustness Test}

In order to ensure the robustness of the model results, we switch the variables as follows to test the model again: using logarithmic patent, dividing the environmental tax and R\&D investment by the operating income, respectively, and delaying the environmental tax by one period. The results were consistent with the above conclusions. Therefore, it can be inferred that the empirical analysis results of the study are robust. Due to the limitation of article space, the analysis results will not be presented here. 


\section{Conclusions and Implications}

\subsection{Conclusions}

Overall, the environmental tax has an obvious promoting effect on the innovation activities of Chinese textile enterprises. Specifically, it can be divided into the promotion of environmental tax on innovation input and on innovation performance.

In terms of the impact of environmental taxes on the innovation investment of Chinese textile enterprises, the study shows that environmental tax can effectively promote the innovation capital input of Chinese textile enterprises, and the innovation manpower input plays a part of the intermediary role (support H1). In other words, on the one hand, environmental tax can directly promote the innovation capital input of Chinese textile enterprises; on the other hand, it can also increase the innovation capital expenditure by increasing the innovation manpower input. After further studying the influence of enterprise heterogeneity factors on environmental tax and innovation investment of textile enterprises, we obtain the following results: (1) industrial factors have an impact on the influence mechanism (support H3b), which is in accordance with the finding of [35]. In the textile subindustry, environmental tax has the most significant promoting effect on enterprises' innovation capital investment, followed by leather and fashion subindustry, while the effect of fiber subindustry is relatively insignificant; (2) the effect of the nature of property rights is not obvious, but environmental tax can relatively better promote enterprise innovation input in nonprivate enterprises; and (3) regional factors have a significant influence (support H3d). In Shandong, Jiangsu, Zhejiang, Fujian, Guangdong, and other major textile provinces of China, environmental tax has a significant promoting effect on innovation investment of textile enterprises.

In terms of the impact of environmental taxes on the innovation performance of Chinese textile enterprises, the study shows that environmental tax can effectively promote the innovation performance of Chinese textile enterprises, and the innovation capital investment plays a complete intermediary role (support H2a). In other words, innovation input is an important bridge between environmental tax and innovation performance, which is also consistent with our previous cognition. After further exploration of the relationship between environmental taxes and textile enterprise innovation's quality and green performance, we find that there is some promoting effect between the environment tax and non-invention/non-green patent of Chinese textile enterprises, which is also supported by [36]. In terms of improving the quality and greening of innovation, there is still a long way to go. It is also verified when the heterogeneity factor of property right nature is considered. In addition, industrial factors also have an impact on environmental tax and enterprise innovation performance (support H3b), consistent with the result of [37], and the promotion effect is more obvious in textile and fiber subindustries. For the factor of property right nature, the promotion effect of the environmental tax on innovation performance is more significant in private textile enterprises (support $\mathrm{H} 3 \mathrm{c}$ ).

To summarize, the results show (1) innovation investment (capital input/manpower input) acts as a bridge between environmental tax and enterprise innovation activities; (2) enterprise heterogeneity plays a significant role in the impact of the environmental tax on innovation input and innovation performance. Compared with previous research, the main contribution of the study is that by testing the micro-level data of Chinese textile enterprises, the study helps us to obtain in-depth and comprehensive research conclusions, guiding policymaking in a more specific way, as the following point one and three mentioned.

\subsection{Policy Implications}

As a market-oriented policy tool, the original intention of environmental tax must be closely related to environmental protection. The government hopes to reduce the negative externalities of production and operation on the environment effectively through this policy instrument. As an effective means for enterprises to overcome the negative externality, technological innovation becomes an indicator of the effectiveness of environmental taxes. 
First of all, more targeted policies are needed to guide green innovation effectively. It can be seen from the research conclusion that environmental tax has a significant promoting effect on the overall innovation of Chinese textile enterprises, but it is far from enough in terms of innovation quality and greening. Moreover, green innovation is a continuous process, and past green innovation experience will affect the level of green innovation in a long period of time [38]. It requires policymakers to consider fully the targeted and persistent guidance of environmental tax on innovation quality and green innovation. For example, measures such as environmental tax exemption for enterprises with new green patents and green invention patents can be considered [39] so as to encourage Chinese textile enterprises to strengthen their green initiatives and quality of technological innovation since the system design of tax incentives will significantly improve the incentive effect on clean production technology innovation [40]. Additionally, appropriate government subsidies can also stimulate enterprises' enthusiasm for green innovation [41].

Secondly, it is urgent to improve the information disclosure mechanism of environmental tax. In the process of the research, we found that it was very difficult to collect environment-related data. No matter environmental tax or green patent, there was a lack of standardized disclosure requirements. It also shows from another aspect that in Chinese textile enterprises, the degree of greening still needs to be improved [42]. The sample data in this study ends in 2018, the first year of the formal implementation of the Environmental Protection Tax Law of the People's Republic of China, and there are very, very few data on the environmental tax of the narrow definition [19], which can be interpreted as most enterprises do not exceed emission limitations and do not need to pay environmental taxes. Further detailed emissions data are not available, which is another sign of the lack of uniform disclosure requirements. Moreover, research shows that mandatory environmental information disclosure can effectively improve the environmental performance of enterprises [42]. The current environmental protection tax is based on the actual discharge of pollutants from enterprises, and therefore, the accuracy of the monitoring data is very important. Foreign experience shows that strong third-party industry associations and other organizations can help the government to effectively manage, reduce the burden of government management, and indeed improve the efficiency of environmental tax policy implementation. The introduction of voluntary reporting can also improve the effectiveness of environmental policies.

In addition, empirical results show the influence of heterogeneous factors on environmental tax and enterprise innovation. Although environmental policies are the same at the national level, the district policymaker can consider issue targeted environmental tax supplement policies for the textile enterprises in different subindustries, different property rights, and different regions. According to the analysis above, we know that the textile and fiber subindustry needs more attention regarding environmental protection than the fashion industry. Some small- and medium-sized private textile enterprises can consider applying cluster management. The local government of Jiangsu, Zhejiang, and other textile industry centralized provinces of China, can also be granted certain autonomy to develop the regional supplementary regulations according to local pollutant emissions and tolerance rate setting to make sure the enterprises' paid taxes and fees can make up for the social loss of enterprise's sewage behavior on the environment [43], better encouraging and strengthening the quality and greening process of Chinese textile enterprise innovation.

Author Contributions: Conceptualization, Y.Y. and H.C.; methodology, Y.Y. and H.C.; software, Y.Y.; validation, Y.Y. and H.C.; formal analysis, Y.Y.; investigation, Y.Y.; resources, Y.Y. and H.C.; data curation, Y.Y. and H.C.; writing-original draft preparation, Y.Y.; writing-review and editing, H.C.; visualization, Y.Y.; supervision, H.C.; project administration, Y.Y. and H.C.; funding acquisition, Y.Y. and H.C. All authors have read and agreed to the published version of the manuscript.

Funding: This research was funded by Philosophy and Social Science Planning Project of Hangzhou, Zhejiang, China, grant number Z19JC046. Soft Science Project of Hangzhou, Zhejiang, China, grant number 20190834M11-2. 
Institutional Review Board Statement: Not Applicable.

Informed Consent Statement: Not Applicable.

Data Availability Statement: Not Applicable.

Acknowledgments: We thank the anonymous reviewers' and editors' suggestions on revision, which is very important for the improvement of the paper.

Conflicts of Interest: The authors declare no conflict of interest.

\section{References}

1. Aldieri, L.; Vinci, C.P. Climate change and knowledge spillovers for cleaner production: New insights. J. Clean. Prod. 2020, 271, 122729. [CrossRef]

2. Wang, H.; Huang, J.; Zhou, H.; Deng, C.; Fang, C. Analysis of sustainable utilization of water resources based on the improved water resources ecological footprint model: A case study of Hubei Province, China. J. Environ. Manag. 2020, 262, 110331. [CrossRef]

3. Lu, H.; Liu, Q.; Xu, X.; Yang, N. Can environmental protection tax achieve "reducing pollution" and "economic growth"? Based on the change perspective of China's sewage charges. China Popul. Resour. Environ. 2019, 29, 130-137.

4. Guo, J. The Effects of Environmental Regulation on Green Technology Innovation-Evidence of the Porter Effect in China. Financ. Trade Econ. 2019, 40, 147-160.

5. Xu, S.; Cheng, L.; Chen, P.; Liu, S.; Gao, J. Changes and Optimization Suggestions on the Fiscal and Tax Policies of Ecological Environment in the 70 Years. Chin. J. Environ. Manag. 2020, 12. [CrossRef]

6. Yu, L.; Zhang, W.; Bi, Q. Can Environmental Taxes Force Corporate Green Innovation? J. Audit Econ. 2019, 34, 79-90.

7. Tong, J.; Wu, K.; Xue, J. Research on Optimizing Environmental Finance and Taxation System in China. NANKAI Econ. Stud. 2017, $6,40-58$.

8. Han, G.; Wang, Y. Research on effect of environmental tax on capacity utilization of manufacturing industry in OECD countries: Enlightenment from high-quality development of China's manufacturing industry. Ind. Econ. Res. 2020, 2, 87-101.

9. Fan, Q.; Zhou, X.; Zhang, T. Externalities of Dynamic Environmental Taxation, Paths of Accumulative Pollution and Long-term Economic Growth. Econ. Res. J. 2016, 51, 116-128.

10. Porter, M.E.; van der Linde, C. Toward a New Conception of the Environment-Competitiveness Relationship. J. Econ. Perspect. 1995, 9, 97-118. [CrossRef]

11. Li, W.; Bi, K.; Sun, B. Research on the Effect of Environmental Regulation Intensity on Green Technological Innovation of Pollution Intensive Industries_Empirical Test Based on Panel Data of 2003-2010. $R$ D Manag. 2013, 25, 72-81.

12. Brunel, C. Green innovation and green Imports: Links between environmental policies, innovation, and production. J. Environ. Manag. 2019, 248, 109290. [CrossRef]

13. Liu, Y.; Yang, X.; Huang, M. Environmental regulation and green total factor productivity: Mediating effect analysis based on different technological progress paths. Contemp. Econ. Manag. 2020, 42, 22-33.

14. Lin, B.; Chen, X. Environmental regulation and energy-environmental performance-Empirical evidence from China's non-ferrous metals industry. J. Environ. Manag. 2020, 269, 110722. [CrossRef] [PubMed]

15. Wang, B.; Zhao, C. China's Green Technological Innovation-Patent Statistics and Influencing Factors. J. Ind. Technol. Econ. 2019, $38,53-66$.

16. Arranz, N.; Arroyabe, M.; Li, J.; Fernandez De Arroyabe, J.C. Innovation as a driver of eco-innovation in the firm: An approach from the dynamic capabilities theory. Bus. Strateg. Environ. 2019, 29, 1494-1503. [CrossRef]

17. Bi, Q.; Yu, L. Environmental tax and enterprise technological innovation: Promotion or suppression? Sci. Res. Manag. 2019, 40, 116-125.

18. Shao, S.; Hu, Z.; Cao, J.; Yang, L.; Guan, D. Environmental Regulation and Enterprise Innovation: A Review. Bus. Strateg. Environ. 2019, 29, 1465-1478. [CrossRef]

19. Yu, L.; Zhang, W.; Bi, Q. The study on the backward forcing effect of environmental tax on corporate green transformation. China Popul. Resour. Environ. 2019, 29, 112-120.

20. Bi, Q.; Yu, L. Relationship between Environmental Taxes and Enterprise Green Investment Behavior: A Panel Quantile Regression Approach. China Popul. Resour. Environ. 2016, 26, 76-82.

21. Bi, Q.; Li, X.; Yu, L. Research on the Heterogeneity of Quantiles between Environmental Tax and Enterprise CompetitivenessPanel Quantile Regression Analysis. Collect. Essays Financ. Econ. 2018, 7, 37-47.

22. Cheng, C.; Ren, X.; Dong, K.; Dong, X.; Wang, Z. How does technological innovation mitigate $\mathrm{CO}_{2}$ emissions in OECD countries? Heterogeneous analysis using panel quantile regression. J. Environ. Manag. 2021, 280, 111818. [CrossRef]

23. Hou, J.; Song, H.; Li, L. Non Research and Development Investment, Knowledge Accumulation and Green Innovation Growth of Manufacturing Industry in China. J. Syst. Manag. 2019, 28, 67-76.

24. Wen, H.; Zhong, Q. Environmental Protection Taxes and Green Technology Innovation of Enterprises-Evidence from the Adjustment of Pollution Charges Standard in China. J. Guizhou Univ. Financ. Econ. 2020, 38, 91-100.

25. Pang, R.; Zheng, D.; Shi, M.; Zhang, X. Pollute first, control later? Exploring the economic threshold of effective environmental regulation in China's context. J. Environ. Manag. 2019, 248, 109275. [CrossRef] [PubMed] 
26. Liu, Y.; Zhang, X. Emission Reduction Effects of Environmental Tax System and Its Regional Differences in China. Tax. Res. 2018, 2, 41-47.

27. Yasmeen, H.; Tan, Q.; Zameer, H.; Tan, J.; Nawaz, K. Exploring the impact of technological innovation, environmental regulations and urbanization on ecological efficiency of China in the context of COP21. J. Environ. Manag. 2020, 274, 111210. [CrossRef]

28. Brown, J.L.; Krull, L.K. Stock Options, R\&D, and the R\&D Tax Credit. Account. Rev. 2008, 83, 705-734.

29. Agostini, L.; Nosella, A.; Filippini, R. Does intellectual capital allow improving innovation performance? A quantitative analysis in the SME context. J. Intellect. Cap. 2017, 18, 400-418. [CrossRef]

30. Vicianová, J.H.; Jad’ud'ová, J.; Hronec, M.; Rolíková, S. Developing Eco-innovation in Business Practice in Slovakia. J. Bus. Econ. Manag. 2017, 18, 1042-1061. [CrossRef]

31. Yu, L.; Li, H.; Wang, Z.; Yunlong, D. Technology imports and self-innovation in the context of innovation quality. Int. J. Prod. Econ. 2019, 214, 44-52. [CrossRef]

32. Chang, C.; Sam, A.G. Corporate environmentalism and environmental innovation. J. Environ. Manag. 2015, 153, 84-92. [CrossRef]

33. Baron, R.M.; Kenny, D.A. The moderator-mediator variable distinction in social psychological research: Conceptual, strategic, and statistical considerations. J. Pers. Soc. Psychol. 1986, 51, 1173-1182. [CrossRef] [PubMed]

34. Judd, C.M.; Kenny, D.A. Process Analysis: Estimating Mediation in Treatment Evaluations. Eval. Rev. 1981, 5, 602-619. [CrossRef]

35. Huang, D.; Duan, H.; Zhang, G. Analysis on the Enterprises' Innovation Quality Based on the Patent Value: A Comparison between Public and Private Enterprises in China. Sustainability 2020, 12, 3107. [CrossRef]

36. Guo, Y.; Xia, X.; Zhang, S.; Zhang, D. Environmental Regulation, Government R\&D Funding and Green Technology Innovation: Evidence from China Provincial Data. Sustainability 2018, 10, 940. [CrossRef]

37. Joo, H.; Suh, H. The Effects of Government Support on Corporate Performance Hedging against International Environmental Regulation. Sustainability 2017, 9, 1980. [CrossRef]

38. Jové-Llopis, E.; Segarra-Blasco, A. Eco-innovation strategies: A panel data analysis of Spanish manufacturing firms. Bus. Strateg. Environ. 2018, 27, 1209-1220. [CrossRef]

39. Zhou, Y.; Shu, C.; Jiang, W.; Gao, S. Green management, firm innovations, and environmental turbulence. Bus. Strateg. Environ. 2019, 28, 567-581. [CrossRef]

40. Tian, C. Master-slave game analysis of environmental tax's influence on green technology innovation of enterprises. Res. Financ. Econ. Issues 2020, 9, 95-104.

41. Tsai, K.; Liao, Y. Sustainability Strategy and Eco-Innovation: A Moderation Model. Bus. Strateg. Environ. 2017, $26,426-437$. [CrossRef]

42. Wu, C.; Yang, S.; Tang, P.; Wu, T.; Fu, S. Construction of the efficiency promotion model of green innovation in China's heavy polluted industries. China Popul. Resour. Environ. 2018, 28, 40-48.

43. Ren, S.; Wei, W.; Sun, H.; Xu, Q.; Hu, Y.; Chen, X. Can mandatory environmental information disclosure achieve a win-win for a firm's environmental and economic performance? J. Clean. Prod. 2020, 250, 119530. [CrossRef] 